\title{
FACTORS ASSOCIATED WITH STROKE: EVIDENCE FROM INDONESIAN FAMILY LIFE SURVEYS 2015
}

\author{
Trisakti Halimah Delimasari'), Vitri Widyaningsih²) \\ ${ }^{1)}$ Masters Program in Public Health, Universitas Sebelas Maret \\ ${ }^{2)}$ Faculty of Medicine, Universitas Sebelas Maret
}

\begin{abstract}
Background: Stroke is a major public health problem, affecting millions of people in both developed and developing countries. In Indonesia stroke prevalence in 2013 rose from $7 \%$ to $10.9 \%$.The purpose of this study was to determine factors associated with stroke using the Indonesian family live survey 5 (IFLS-5) year 2015.

Subjects and Method: This was a cross sectional study. A sample of 34,250 study subject aged $\geq 18$ years old was selected for this study. The dependent variable was stroke. The independent variables were age, gender, body mass index (BMI), hypertension, cholesterol level, and diabetes mellitus. The data were analyzed by a multiple logistic regression.

Results: The risk of stroke increased with age $\geq 40$ years old $(\mathrm{OR}=5.09 ; 95 \% \mathrm{CI}=3.13$ to 8.26; $\mathrm{p}=0.001)$, male $(\mathrm{OR}=1.86 ; 95 \% \mathrm{CI}=1.36$ to $2.52 ; \mathrm{p}=0.001)$, hypertension $(\mathrm{OR}=8.71$; $95 \% \mathrm{CI}=6.09$ to 12,$46 ; \mathrm{p}=0.001)$, diabetes mellitus $(\mathrm{OR}=1.89 ; 95 \% \mathrm{CI}=1.22$ to $2.95 ; \mathrm{p}=$ $0.004)$, and cholesterol level $(\mathrm{OR}=3.42 ; 95 \% \mathrm{CI}=2.35$ to $4.99 ; \mathrm{p}=0.001)$. The risk of stroke decreased with normal $\mathrm{BMI}(\mathrm{OR}=0.75 ; 95 \% \mathrm{CI}=0.58$ to $0.96 ; \mathrm{p}=0.026)$.

Conclusion: The risk of stroke increases with age $\geq 40$ years old, male, hypertension, cholesterol level, and diabetes mellitus. The risk of stroke decreases with normal BMI.
\end{abstract}

Keywords: stroke, Indonesian family life survey 5

\section{Correspondence:}

Trisakti Halimah Delimasari. Masters Program in Public Health, Universitas Sebelas Maret. Jl. Ir. Sutami 36A, Surakarta 57126, Central Java, Indonesia. Email: trisaktihd1994@gmail.com. Mobile:+6285293994629.

The $7^{\text {th }}$ International Conference on Public Health Solo, Indonesia, November 18-19, 2020 | 79 https://doi.org/10.26911/the7thicph.01.34 